\title{
Antibiotically active metabolites from Talaromyces wortmannii, an endophyte of Aloe vera
}

\author{
Robert Bara ${ }^{1}$, Amal H Aly ${ }^{1}$, Alexander Pretsch ${ }^{2}$, Victor Wray ${ }^{3}$, Bingui Wang ${ }^{4}$, Peter Proksch ${ }^{1}$ and \\ Abdessamad Debbab ${ }^{1}$
}

The Journal of Antibiotics (2013) 66, 491-493; doi:10.1038/ja.2013.28; published online 15 May 2013

Keywords: Aloe vera; antibiotic activity; endophyte; structure elucidation; Talaromyces wortmannii

Endophytes are microbes that colonize the internal tissues of plants without causing any immediate overt negative effects. ${ }^{1}$ They are considered as a promising source of new natural drug leads that are of great potential for medicinal and agricultural applications. ${ }^{2,3}$ For instance, many of the products currently used for human or animal therapy, in animal husbandry and in agriculture, are produced by microbial products, or are derived from them. ${ }^{4}$ Furthermore, with the increasing incidence of drug resistance in human pathogenic bacteria, which are among the major causes of deaths worldwide, ${ }^{5,6}$ there is an urgent need for new bioactive secondary metabolites.

As part of our ongoing research focused on the discovery of new bioactive natural products from endophytic fungi, ${ }^{7,8}$ we studied the chemical constituents of the strain Talaromyces wortmanii, which was isolated from healthy tissues of Aloe vera collected in Alexandria, Egypt. Fungi of the genus Talaromyces have been found in solitary, as well as endophytic states in various climates worldwide from terrestrial to marine-influenced environment. ${ }^{9}$ This genus has been investigated by many researchers as it produces a plethora of interesting compounds such as tetraene lactones, ${ }^{9}$ diphenyl ether derivatives and anthraquinones, ${ }^{10}$ which show various biological activities ranging from antibiotics to cytotoxins. ${ }^{9-11}$ In the present study, we report the isolation and structure elucidation of a new atropisomer (1) a new wortmannin derivative (2) and two wortmannin derivatives (3-4) that were hitherto known only as synthetic products, as well as seven known metabolites (5-11). Furthermore, we evaluated the antibiotic activity of the isolated compounds against several pathogenic Gram positive and negative bacteria.

The endophytic fungus was isolated from healthy inner tissues of Aloe vera and then identified as T. wortmanii according to a molecular biological protocol by DNA amplification and sequencing of the ITS region. The fungal strain was cultured on rice medium for 4 weeks and then extracted with EtOAc to give $5 \mathrm{~g}$ of extract, which was fractionated by vacuum liquid chromatography with $n$-hexane,
$n$-hexane/EtOAc, $\mathrm{CH}_{2} \mathrm{Cl}_{2}$ and $\mathrm{CH}_{2} \mathrm{Cl}_{2} / \mathrm{MeOH}$ gradient elution. Obtained fractions were separated by Sephadex LH-20 using $\mathrm{MeOH}$ as solvent system, and the compounds (1-11) (Scheme 1) were finally purified by semi-preparative HPLC.

Compound 1 was obtained as an orange amorphous powder. It showed UV absorption maxima identical to those of emodin. ${ }^{12}$ ESIMS data of 1 showed a base peak at $m / z 537.3[\mathrm{M}-\mathrm{H}]^{-}(-\mathrm{ve})$, which inferred that 1 has a MW of $538 \mathrm{~g} \mathrm{~mol}^{-1}$. The molecular formula was established as $\mathrm{C}_{30} \mathrm{H}_{18} \mathrm{O}_{10}$ based on the prominent signals detected at $m / z 539.0971[\mathrm{M}+\mathrm{H}]^{+}$and $561.0787[\mathrm{M}+\mathrm{Na}]^{+}(+\mathrm{ve})$ in the HRESIMS. In contrast, the ${ }^{13} \mathrm{C}$ NMR data of 1 (Table 1) showed signals corresponding to 15 carbons only, indicating that $\mathbf{1}$ is a symmetrical dimer consisting of two identical monomers. ${ }^{1} \mathrm{H}$ NMR showed proton signals of one aromatic methyl group resonating at $\delta_{\mathrm{H}}$ 2.49 p.p.m., one aromatic singlet at $\delta_{\mathrm{H}} 7.47$ p.p.m. and two aromatic broad singlets resonating at $\delta_{\mathrm{H}} 7.17$ and 7.62 p.p.m. The ${ }^{13} \mathrm{C} \mathrm{NMR}$ data (Table 1) exhibited 15 carbon peaks attributable to one methyl group, three methine carbons and 11 quaternary carbon atoms. Further analysis of the ${ }^{13} \mathrm{C}$ spectrum disclosed signals for two carbonyl groups resonating at $\delta_{\mathrm{C}} 186.0\left(\mathrm{C}-9 / 9^{\prime}\right)$ and $182.0\left(\mathrm{C}-10 / 10^{\prime}\right)$, three oxygenated aromatic carbon atoms at $\delta_{\mathrm{C}} 164.0\left(\mathrm{C}-1 / 1^{\prime}\right)$, $156.0\left(\mathrm{C}-6 / 6^{\prime}\right)$ and $163.5\left(\mathrm{C}-8 / 8^{\prime}\right)$ and nine aromatic carbons at $\delta_{\mathrm{C}}$ $124.9\left(\mathrm{C}-2 / 2^{\prime}\right), 150.0\left(\mathrm{C}-3 / 3^{\prime}\right), 121.5\left(\mathrm{C}-4 / 4^{\prime}\right), 134.2\left(\mathrm{C}-4 \mathrm{a} / 4 \mathrm{a}^{\prime}\right), 109.0$ $\left(\mathrm{C}-5 / 5^{\prime}\right), 114.1\left(\mathrm{C}-7 / 7^{\prime}\right), 110.1\left(\mathrm{C}-8 / 8 \mathrm{a}^{\prime}\right), 115.0\left(\mathrm{C}-9 \mathrm{a} / 9 \mathrm{a}^{\prime}\right)$ and $\delta_{\mathrm{C}}$ $137.0\left(\mathrm{C}-10 \mathrm{a} / 10 \mathrm{a}^{\prime}\right)$. Comparison of NMR data and UV spectra of $\mathbf{1}$ with those of emodin, as well as consideration of the MW, suggested that $\mathbf{1}$ is a symmetrical dimer of two emodin units. The linkage between the emodin building blocks was confirmed by 2D NMR analysis, including ${ }^{1} \mathrm{H}-{ }^{1} \mathrm{H}$ COSY and $J^{2} / J^{3}$ HMBC correlations (Supplementary Figure $\mathrm{S} 1$ ). ${ }^{1} \mathrm{H}-{ }^{1} \mathrm{H}$ COSY spectrum showed that the aromatic methyl signal correlated to the meta-coupled protons $\mathrm{H}-2$ and $\mathrm{H}-4$. The absence of the second set of meta-coupled protons and the presence of one aromatic singlet in 1 compared with emodin,

${ }^{1}$ Institut für Pharmazeutische Biologie und Biotechnologie, Heinrich-Heine-Universität Düsseldorf, Düsseldorf, Germany; ${ }^{2}$ SeaLife Pharma GmbH, Tulln, Austria; ${ }^{3}$ Helmholtz Centre for Infection Research, Braunschweig, Germany and ${ }^{4}$ Laboratory of Experimental Marine Biology, Institute of Oceanology, Chinese Academy of Science, Quindao, China Correspondence: Dr A Debbab, Institut für Pharmazeutische Biologie und Biotechnologie, Heinrich-Heine-Universität Düsseldorf, Universitätsstrasse 1, Geb. 26.23, Düsseldorf 40225, Germany.

E-mail: abdessamad.debbab@uni-duesseldorf.de

Received 13 November 2012; revised 12 March 2013; accepted 20 March 2013; published online 15 May 2013 

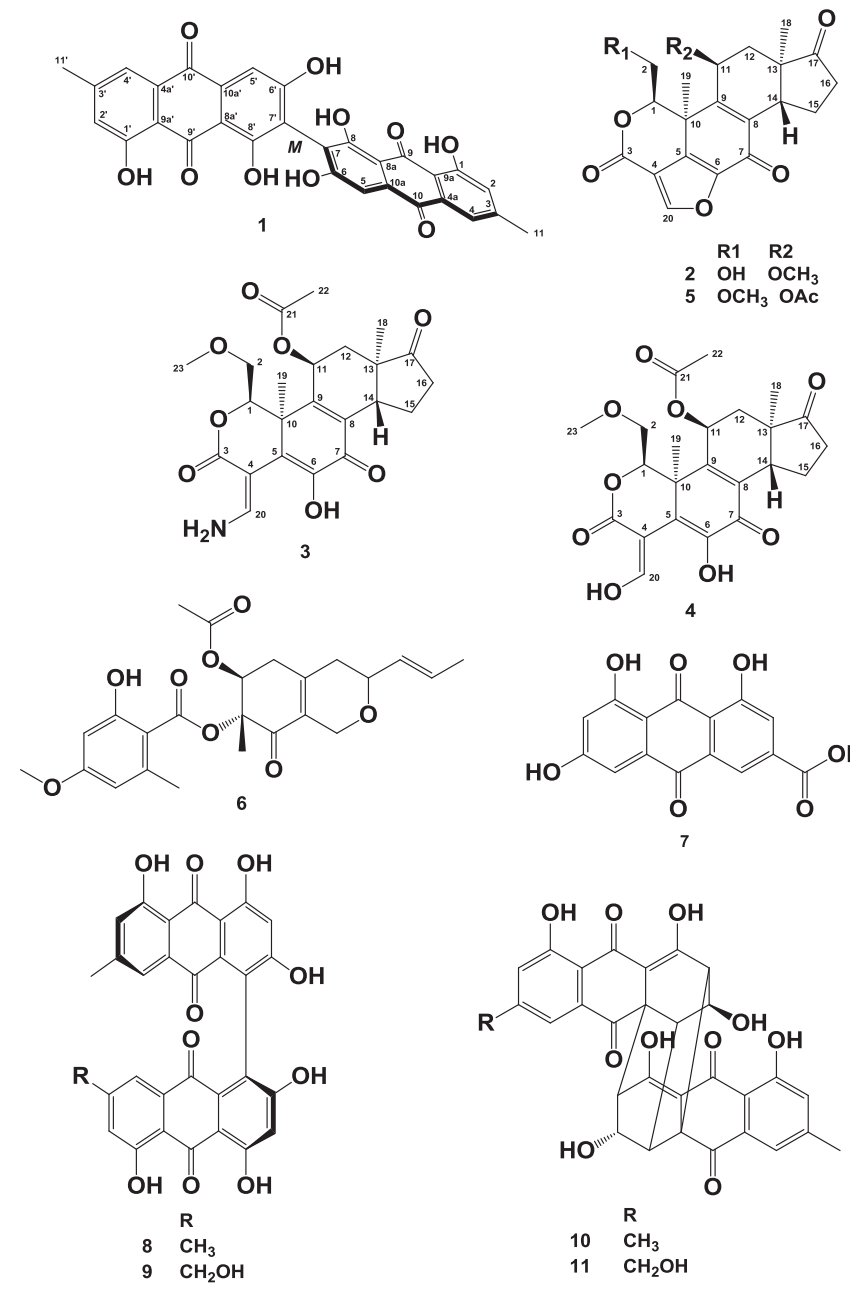

Scheme 1 Structures of isolated compounds.

confirmed the previous assumption and indicated either a 5,5'- or a $7,7^{\prime}$-linkage of the two emodin moieties. Inspection of the HMBC spectrum showed that $\mathrm{CH}_{3}-11$ correlated to C-2, C-3 and C-4, and the aromatic singlet proton observed at $\delta_{\mathrm{H}} 7.47$ p.p.m. together with $\mathrm{H}-4 / 4^{\prime}$ showed strong $J^{3}$ correlations to the carbonyl carbons $\mathrm{C}-10 / 10^{\prime}$ (Supplementary Figure $\mathrm{S} 1$ ). Thus, the protons resonating at $\delta_{\mathrm{H}} 7.47$ p.p.m. were assigned to $H-5 / 5^{\prime}$ and a $7,7^{\prime}$-linkage was established. Furthermore, comparison with NMR data of structurally related anthranoids, isolated in our previous studies, ${ }^{7,8,12}$ revealed that in such systems the two meta-coupled aromatic protons $\mathrm{H}-5 / 5^{\prime}$ and $\mathrm{H}-7 / 7^{\prime}$ resonate at considerably different chemical shifts with $\mathrm{H}-5 / 5^{\prime}$ consistently appearing more downfield than $\mathrm{H}-7 / 7^{\prime}$ (ca. $7.0<\delta_{\mathrm{H}}<7.2$ ). In addition, a 5,5'-linkage between the two emodin moieties forms the known skyrin, ${ }^{13}$ which was likewise isolated from T. wortmanii in this study. Accordingly, the $7,7^{\prime}$-linkage of the emodin building blocks to form the new atropisomer 1 was unambiguously confirmed. Compound $\mathbf{1}$ is an atropisomer resulting from hindered rotation of two symmetrical moieties (emodin) around the biaryl axis, thus the axial chirality was determined by a CD experiment. The CD spectrum exhibited a positive Cotton effect at shorter wavelength and a negative one at longer wavelength, which is typical for the $M$-conformer (also known as 'A-type' or $\mathrm{a} R$ ). This was also in agreement with the $[\alpha]_{\mathrm{D}}$ value of -156 . Accordingly, $\mathbf{1}$ is a new natural product consisting of two emodin moieties, for which the name biemodin is proposed.
Table 1 NMR spectroscopic data of 1 and 2 at $600\left({ }^{1} \mathrm{H}\right)$ and 150 $\left({ }^{13} \mathrm{C}\right) \mathrm{MHz}\left(\mathrm{CDCl}_{3}\right)$

\begin{tabular}{|c|c|c|c|c|c|}
\hline \multirow[b]{2}{*}{ Nr. } & \multicolumn{2}{|r|}{1} & \multirow[b]{2}{*}{$N r$} & \multicolumn{2}{|r|}{2} \\
\hline & $\delta_{C^{a}}$ & $\delta_{H}(\mathrm{~J}$ in $\mathrm{Hz})$ & & $\delta_{C}{ }^{a}$ & $\delta_{H}(J$ in $H z)$ \\
\hline $1 / 1^{\prime}$ & 164.0 & \multirow[b]{2}{*}{$7.17(1 \mathrm{H} ; \mathrm{br} \mathrm{s})$} & 1 & 84.9 & \multirow{12}{*}{$\begin{array}{c}4.65(1 \mathrm{H} ; \mathrm{t} ; 4.0) \\
2.96(1 \mathrm{H} ; \mathrm{dd} ; 4.0,10.5) \\
3.07 \text { (1H; dd; 4.0; 10.6) }\end{array}$} \\
\hline $2 / 2^{\prime}$ & 124.9 & & 2 & 74.3 & \\
\hline $3 / 3^{\prime}$ & 150.0 & \multirow{10}{*}{$\begin{array}{c}7.62(1 \mathrm{H} ; \mathrm{br} \mathrm{s}) \\
7.47(1 \mathrm{H} ; \mathrm{s})\end{array}$} & 3 & 160.7 & \\
\hline $4 / 4^{\prime}$ & 121.5 & & 4 & 116.8 & \\
\hline $4 a / 4 a^{\prime}$ & 134.2 & & 5 & 136.6 & \\
\hline $5 / 5^{\prime}$ & 109.0 & & 6 & 148.2 & \\
\hline & 156.0 & & 7 & 174.2 & \\
\hline & 114.1 & & 8 & 139.0 & \\
\hline $8 / 8^{\prime}$ & 163.5 & & 9 & 149.1 & \\
\hline $8 a / 8 a^{\prime}$ & 110.1 & & 10 & 45.5 & \\
\hline $9 / 9^{\prime}$ & 186.0 & & 11 & 53.7 & \\
\hline $9 a / 9 a^{\prime}$ & 115.0 & & 12 & 35.4 & \\
\hline \multirow{10}{*}{$\begin{array}{l}10 / 10^{\prime} \\
10 \mathrm{a} / 10 \mathrm{a}^{\prime} \\
11 / 11^{\prime} \\
\mathrm{OH} / \mathrm{OH}^{\prime}\end{array}$} & 182.0 & \multirow{10}{*}{$\begin{array}{l}2.49 \\
12.09 \\
12.58\end{array}$} & 13 & 49.5 & \\
\hline & 137.0 & & 14 & 45.5 & $2.98(1 \mathrm{H} ; \mathrm{m})$ \\
\hline & 21.9 & & 15 & 24.6 & $2.02(2 \mathrm{H} ; \mathrm{m})$ \\
\hline & & & 16 & 38.3 & $2.25(1 \mathrm{H} ; \mathrm{m})$ \\
\hline & & & 17 & - & $2.61(1 \mathrm{H} ; \mathrm{m})$ \\
\hline & & & 18 & 18.8 & 1.01 (3H; s) \\
\hline & & & 20 & & $8.23(1 \mathrm{H} ; \mathrm{s})$ \\
\hline & & & 21 & 171.3 & \\
\hline & & & $\begin{array}{l}22 \\
23\end{array}$ & $\overline{59.6}$ & 2.98 (3H; s) \\
\hline & & & $\mathrm{OH}$ & & $3.47(1 \mathrm{H} ; \mathrm{br} . \mathrm{s})$ \\
\hline
\end{tabular}

aDerived from HMBC spectrum.

Compound 2 was obtained as a light brown amorphous powder with UV absorption maxima resembling those of wortmannin (5), likewise isolated during this study. The HRESIMS exhibited a prominent peak at $m / z 387.1436[\mathrm{M}+\mathrm{H}]^{+}(+$ve), with a 42 mass unit decrease compared with the MW of 5 , which established the molecular formula $\mathrm{C}_{21} \mathrm{H}_{22} \mathrm{O}_{7}$ for 2. Comparison of the ${ }^{1} \mathrm{H}$ NMR spectra of $\mathbf{2}$ and $\mathbf{5}$ showed a close relationship between both compounds, except for the presence of an additional hydroxyl group and the absence of the $\mathrm{O}$-acetyl group in 2. Further analysis of 2D NMR data of $\mathbf{2}$ and $\mathbf{5}$ confirmed that both share similar skeletons and substituents, except for the replacement of the acetyl function in $\mathbf{5}$ by an aliphatic methoxy group and the presence of a free hydroxyl group at C-2 in 2 (Supplementary Figure S2). In analogy to 5, three spin systems, including $\mathrm{CH}(1) \mathrm{CH}_{2}(2) \mathrm{OH}, \quad \mathrm{CH}_{2}(12) \mathrm{CH}(11)$ and $\mathrm{CH}_{2}(16) \mathrm{CH}_{2}(15) \mathrm{CH}(14)$ were detected in the ${ }^{1} \mathrm{H}-{ }^{1} \mathrm{H}$ COSY spectrum of 2. In addition, the HMBC spectrum confirmed the assignments of these spin systems. In contrast to 5, the signal of the aliphatic methoxy group of 2 exhibited a strong $J^{3}$ HMBC correlation to a carbon resonating at $\delta_{\mathrm{C}} 53.7$ p.p.m. which was attributed to C-11. Hence, $\mathrm{CH}_{2}-2$ is connected to the additional free hydroxyl group, whereas the methoxy group is attached to $\mathrm{C}-11$. Thus, the planar structure of $\mathbf{2}$ was accomplished. The relative configuration of $\mathbf{2}$ was deduced from analysis of the coupling constants and comparison to those of $\mathbf{5}$. Furthermore, comparison of the $[\alpha]_{D}$ values of $\mathbf{2}(+18.8)$ and $5(+44)$ and biogenetic considerations suggest that both compounds share the same absolute configuration. Accordingly, 2 was identified as a new wortmannin derivative for which the name wortmannin B is proposed.

Compound 3-11 were identified on the basis of their ${ }^{1} \mathrm{H}$ and ${ }^{13} \mathrm{C}$ NMR, mass spectrometric data, $[\alpha]_{\mathrm{D}}$ values and comparison with published data as amino adduct $3 \mathrm{a}(3),{ }^{14}$ wortmannin-diol (VIII) (4), ${ }^{15}$ wortmannin (5), ${ }^{15}$ wortmin $(6),{ }^{16}$ emodic acid (7),${ }^{17}$ skyrin $(8),{ }^{13}$ 
oxyskyrin (9), ${ }^{18}$ rugulosin A (10) and B (11).${ }^{19}$ We report here the complete NMR data $\left({ }^{1} \mathrm{H},{ }^{13} \mathrm{C}\right.$, DEPT, COSY, HMBC, HMQC and ROESY, Supplementary Figures S11 to S24) for compounds 3 and 4 for the first time.

All compounds, except 7 and 9 due to their small amounts, were tested for their antibiotic activity against pathogenic Gram negative bacteria, including Escherichia coli, Klebsiella pneumonia, Pseudomonas aeruginosa, Acinetobacter baumannii, Enterobacter sp. and Enterococcus cloacae and Gram positive bacteria, including Methicillin-resistant Staphylococcus aureus (MRSA), Staphylococcus epidermidis, Streptococcus pneumonia, and Enterococcus faecalis (Supplementary Table S3). Among the tested compounds, $\mathbf{8}$ and $\mathbf{1 0}$ exhibited considerable antibiotic activity against Gram positive pathogenic bacteria with MIC values ranging between 4 and $16 \mu \mathrm{g} \mathrm{ml}^{-1}$. The new biemodin (1) also showed strong activity against Gram positive bacteria, especially against MRSA, but was less active compared to compounds $\mathbf{8}$ and $\mathbf{1 0}$.

Biemodin (1): orange amorphous powder. $[\alpha]_{D^{-15}}^{20}$ (c 0.02 , $\left.\mathrm{CHCl}_{3}\right) . \mathrm{UV}: \lambda_{\max }(\mathrm{PDA})=223,255,291$ and $450 \mathrm{~nm} . \mathrm{CD}\left(\mathrm{CHCl}_{3}\right.$, $\left.c=3.7110^{-3} \mathrm{M}\right): \lambda_{\max }(\Delta \varepsilon)=263(0.624), 291(-1.80), 316(-1.59)$, $374(-1.08), 470$ (-2.94), 507 (-2.38). ESIMS ( $-\mathrm{ve}): m / z=537.3$ $[\mathrm{M}-\mathrm{H}]^{-}$. HRESIMS: calcd. for $\mathrm{C}_{30} \mathrm{H}_{19} \mathrm{O}_{10}[\mathrm{M}+\mathrm{H}]^{+}$539.0978; found $539.0971[\mathrm{M}+\mathrm{H}]^{+}$and for $\mathrm{C}_{30} \mathrm{H}_{18} \mathrm{O}_{10} \mathrm{Na}[\mathrm{M}+\mathrm{Na}]^{+}$ 561.0798; found 561.0787. ${ }^{1} \mathrm{H}$ and ${ }^{13} \mathrm{C}$ NMR data, see Table 1.

Wortmannin B (2): light brown amorphous powder. $[\alpha]_{\mathrm{D}}^{20}+18.8(c$ $0.02, \mathrm{MeOH}) . \mathrm{UV}: \lambda_{\max }(\mathrm{PDA})=210,259$ and $300 \mathrm{~nm}$. ESIMS $(+\mathrm{ve})$ : $m / z=386.8[\mathrm{M}+\mathrm{H}]^{+}$and $794.9[2 \mathrm{M}+\mathrm{Na}]^{+} ;(-\mathrm{ve}): \mathrm{m} / z 385.0$ $[\mathrm{M}-\mathrm{H}]^{-}$and $770.8[2 \mathrm{M}-\mathrm{H}]^{-}$. HRESIMS: calcd. for $\mathrm{C}_{21} \mathrm{H}_{23} \mathrm{O}_{7}[\mathrm{M}+$ $\mathrm{H}]^{+}$387.1444; found 387.1436. ${ }^{1} \mathrm{H}$ NMR data, see Table 1.

\section{ACKNOWLEDGEMENTS}

This study was supported by grants of the BMBF awarded to PP and AD RB wishes to thank DAAD for a scholarship. B-GW and PP acknowledge the support of a joint project from NSFC (30910103914).
1 Bacon, C. W. \& White, J. F. Microbial Endophytes (Marcel Dekker, Inc., New York, 2000).

2 Aly, A. H., Debbab, A. \& Proksch, P. Fungal endophytes: unique plant inhabitants with great promises. Appl. Microbiol. Biotechnol. 90, 1829-1845 (2011).

3 Debbab, A., Aly, A. \& Proksch, P. Endophytes and associated marine derived fungiecological and chemical perspectives. Fungal Divers. 57, 45-83 (2012).

4 Donadio, S. et al. Microbial technologies for the discovery of novel bioactive metabolites. J. Biotechnol. 99, 187-198 (2002).

5 Knight, G. M. et al. Shift in dominant hospital-associated methicillin-resistant Staphylococcus aureus (HA-MRSA) clones over time. J. Antimicrob. Chemother. 67, 2514-2522 (2012).

6 MacDougall, C., Powell, J. P., Johnson, C. K., Edmond, M. B. \& Polk, R. E. Hospital and community fluoroquinolone use and resistance in Staphylococcus aureus and Escherichia coli in 17 US hospitals. Clin. Infect. Dis. 41, 435-440 (2005).

7 Debbab, A et al. New anthracene derivatives - structure elucidation and antimicrobial activity. Eur. J. Org. Chem. 1351-1359 (2012).

8 Aly, A. H. et al. NF kappa B inhibitors and antitrypanosomal metabolites from endophytic fungus Penicillium sp. isolated from Limonium tubiflorum. Bioorg. Med. Chem. 19, 414-421 (2011).

9 Yuesheng, D. et al. Cathepsin B inhibitory tetraene lactones from the fungus Talaromyces wortmannii. Helv. Chim. Acta. 92, 567-574 (2009).

$10 \mathrm{Liu}, \mathrm{F}$. et al. The bioactive metabolites of the mangrove endophytic fungus Talaromyces sp. ZH-154 isolated from Kandelia candel (L.) Druce. Planta Med. 76, 185-189 (2010).

11 Wakelin, S., Warren, R., Harvey, P. \& Ryder, M. Phosphate solubilization by Penicillium spp. closely associated with wheat roots. Biol. Fert. Soils 40, 36-43 (2004)

12 Debbab, A. \& Aly, A. H. et al. Bioactive metabolites from the endophytic fungus Stemphylium globuliferum isolated from Mentha pulegium. J. Nat. Prod. 72, 626-631 (2009).

13 Vargas, F., Rivas, C., Zoltan, T., López, V., Ortega, J., Izzo, C., Pineda, M., Medina, J., Medina, E. \& Rosales, L. Antioxidant and scavenging activity of skyrin on free radical and some reactive oxygen species. Av. Quim. 3, 7-14 (2008).

14 Norman, B. H., Shih, C., Toth, J. E., Ray, J. E., Dodge, J. A., Johnson, D. W., Rutherford, P. G., Schultz, R. M., Worzalla, J. F. \& Vlahos, C. J. Studies on the mechanism of phosphatidylinositol 3-kinase Inhibition by wortmannin and related analogs. J. Med. Chem. 39, 1106-1111 (1996).

15 MacMillan, J., Vanstone, A. E. \& Yeboah, S. K. Fungal products. Part III. Structure of wortmannin and some hydrolysis products. J. Chem. Soc. Perkin Trans. 1, 2898-2903 (1972).

16 Merlini, L., Mondelli, R., Nasini, G. \& Hesse, M. Structure of wortmin, a new metabolite from Penicillium wortmanni. Helv. Chim. Acta. 56, 232-239 (1973).

17 Alvi, K. A., Nair, B., Gallo, C. \& Baker, D. Screening of microbial extracts for tyrosine kinase inhibitors. J. Antibiot. 50, 264-266 (1997).

18 Shibata, S., Takido, M., Ohta, A. \& Kurosu, T. Metabolic products of fungi. XIII. The structure of oxyskyrin. Pharm. Bull 5, 573-575 (1957).

19 Hiroyuki, Y., Nobuhiro, K., Satoshi, O. \& Hiroshi, T. new rugulosins, anti-MRSA antibiotics, produced by Penicillium radicum FKI-3765-2. Org. Lett. 12, 1572-1575 (2010).

Supplementary Information accompanies the paper on The Journal of Antibiotics website (http://www.nature.com/ja) 